\title{
Pengendalian Tikus Di Lahan Pertanian Melalui Program Rumah Burung Hantu Oleh Kelomtan "Sumber" Desa Baleeatur
}

\author{
Genesiska, Diah Rina Kamardiani, Azmi Sanjaya Wahyu Murti, Afifatul Khoirunnisa, Nur \\ Rokhim, dan Hariyono
}

Prodi Agroteknologi, Fakultas Pertanian, Universitas Muhammadiyah Yogyakarta, Jalan Brawijaya, Kasihan, Bantul Yogyakarta 55183 Email: genesiska@umy.ac.id

DOI: $10.18196 / \mathrm{ppm} .36 .324$

\begin{abstract}
Abstrak
Serangan hama tikus pada lahan budidaya padi mampu menurunkan kualitas maupun kuantitas hasil, bahkan sampai menyebabkan kegagalan panen. Kerugian ekonomi besar-besaran terjadi bagi kelompok tani sumber di Desa Balecatur, Kabupaten Sleman akibat serangan tikus di lahan budidaya tanaman padi. Sejak tahun 2017 atau sudah 6 kali masa tanam, masyarakat di Desa Balecatur telah mengalami kegagalan budidaya komoditas pertanian. Diperlukan suatu upaya untuk pengendalian hama tikus yang berkelanjutan dan tidak memiliki resiko besar terhadap lingkungannya. Program yang dijalankan diputuskan memiliki 4 kegiatan inti yaitu perumusan konsep dan jenis program rumah burung hantu, penentuan lokasi habitat burung hantu dan analisis jelajahnya, pemasangan rumah burung hantu, sosialisasi dengan perangkat desa dan warga masyarakat sekitar dan monitoring program rubuha. program kemitraan kemudian secara teknis didasarkan pada keberadaan burung hantu tyto alba di kawasan dekat hamparan sawah milik kelompok tani sumber dan perlu didukung oleh seluruh anggota masyarakat baik kelompok tani bersangkutan, warga sekitar, maupun perangkat desa yang bertugas dalam pengaturan hukum dalam proses pelaksanaannya.
\end{abstract}

Kata Kunci: burung hantu, pertanian, tikus

\section{Pendahuluan}

Balecatur adalah desa yang terletak di Kecamatan Gamping, Sleman, Daerah Istimewa Yogyakarta, Indonesia. Desa Balecatur dengan luas 931.705 ha terdiri dari 18 padukuhan, dengan 54 RW dan 130 RT. Jumlah Penduduk Desa Balecatur sebanyak 16.446 jiwa yang terdiri atas 4.141 KK. Dengan luas sawah 306,6 ha, bangunan pekarangan seluas 497,6 ha. Kepadatan penduduk desa Balecatur luas $9,86 \mathrm{~km}^{2}$ dengan kepadatan penduduk per $\mathrm{km}^{2} 3,085$. Sebagian besar penduduk desa balecatur berprofesi sebagai petani sehingga desa Balecatur mampu menghasilkan rata-rata produksi $68,32 \mathrm{Kw} / \mathrm{Ha}$ dengan produksi $63,196 \mathrm{kw}$ dengan luas tanam $952 \mathrm{Ha}$.

Kerugian ekonomi besar besaran terjadi bagi kelompok tani sumber di Desa Balecatur, Kabupaten Sleman akibat serangan tikus di lahan budidaya tanaman padi. Sejak tahun 2017 atau sudah 6 kali masa tanam, masyarakat di Desa Balecatur telah mengalami kegagalan budidaya komoditas apapun, (Gambar 1). Hal ini disebabkan oleh populasi tikus yang semakin banyak, dan dimungkinkan rusaknya rantai ekosistem sawah di desa tersebut. Upaya mekanik maupun kimiawi sudah coba dilakukan masyarakat, seperti menggunakan racun tikus, jebakan tikus, sampai perburuan tikus secara beramai-ramai dengan melibatkan masyarakat desa Balecatur. Akan tetapi, berbagai usaha penanggulangan tersebut belum mampu mengendalikan populasi tikus yang tetap tinggi. Pada kondisi saat ini, kelompok tani digolongkan dalam mitra yang tidak produktif secara ekonomi maupun sosial. 


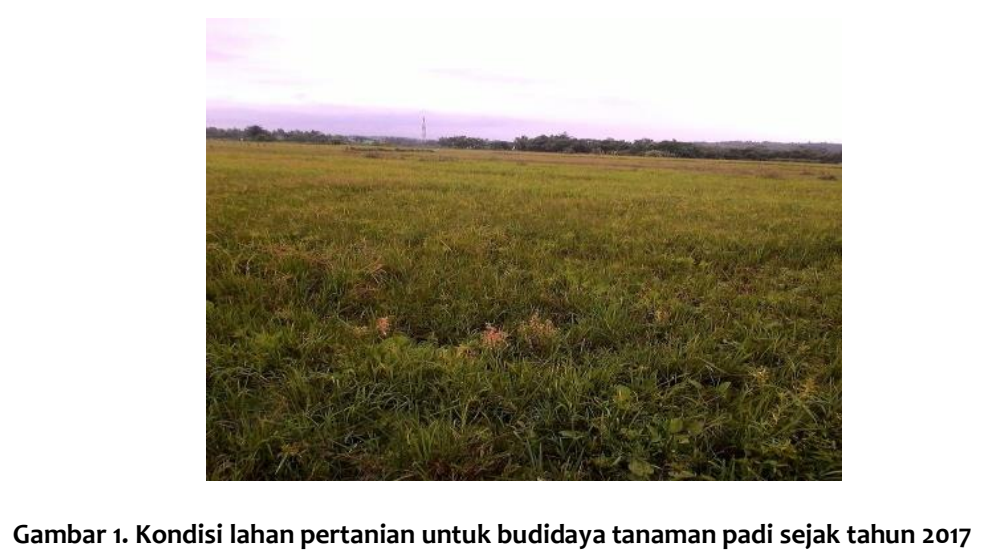

Potensi yang sebenarnya dapat dikembangkan oleh kelompok tani sangatlah besar dalam hal budidaya tanaman padi ataupun komoditas lainnya. Terdapat suatu cara alami yang memungkinkan dapat membantu mitra yang sudah tidak produktif lagi secara ekonomi maupun sosial dengan pengembangan kelembagaan kelompok taninya dan melakukan upaya yang terbaik untuk mengendalikan populasi tikus sehingga mata pencaharian tidak hilang sekaligus dapat mempertahankan lahan untuk bercocok tanam yang semakin hari semakin sempit.

Peluang yang ditawarkan dalam program ini diharapkan kelompok tani dapat mengenal, menyadari, dan merasakan bahwa menyeimbangkan ekosistem dengan cara alami perlu dilakukan. Hal ini tidak dapat dilakukan hanya individu saja tapi kesadaran individu yang bekerja sama dalam suatu kelembagaan. Seperti yang disampaikan oleh Sururi dan Mulyasih (2017) bahwa dapat dilakukan penguatan kemampuan yang dimiliki oleh setiap individu dalam masyarakat, kelembagaan, maupun sistem atau jejaring antarindividu dan kelompok/organisasi sosial serta pihak lain diluar sistem masyarakatnya sampai di aras global (Sururi \& Mulyasih, 2017), khususnya kelembagaan kelompok tani sumber di Desa Balecatur.

Hanya saja, terdapat beberapa kendala dalam pengembangan kapasitas kelompok tani dalam mengendalikan tikus. Selama ini, dari berbagai aspek kelompok tani mengalami keterbatasan sebagai berikut.

a. Keterbatasan memperoleh layanan kelembagaan dalam memberikan kesadaran dan pemahaman kepada Kelompok Tani "Sumber" terkait ekosistem dan rantai makanan

b. Keterbatasan layanan pendidikan dalam teknis pembuatan dan penerapan rumah burung hantu di daerah pematang lahan budidaya tanaman padi

c. Keterbatasan layanan dalam program rehabilitasi ekosistem untuk menggalakkan kembali budidaya tanaman di lahan.

Terkait dengan berbagai paparan tersebut, terdapat potensi pembangunan rumah burung hantu yang perlu dipahami, diyakini, dan dikuasai tekniknya untuk bisa mengarahkan burung hantu dalam mengendalikan populasi hama tersebut. Oleh karena itu perlu dilakukan suatu upaya "Pengembangan Kapasitas Kelompok Tani Sumber Desa Balecatur dalam Mengendalikan Populasi Tikus di Lahan Pertanian melalui Program Rumah Burung Hantu”.

\section{Metode Pelaksanaan}

Untuk mencapai target luaran sesuai permasalahan prioritas yang dihadapi, dilakukan berbagai upaya pelaksanaan dengan beberapa metode yang meliputi penyuluhan, fasilitasi peralatan dan transfer teknologi, pelatihan dan praktek aplikasi teknologi, serta pendampingan dan monitoring evaluasi. Rincian metode pelaksanaan kegiatan selengkapnya disajikan pada Tabel 2. 
Tabel 2. Metode pelaksanaan kegiatan pengembangan kapasitas kelompok tani sumber di Desa Balecatur Sleman dalam mengendalikan tikus melalui Rumah Burung hantu Tyto alba

\begin{tabular}{|c|c|c|}
\hline No & Target Luaran Kegiatan & Metode Pelaksanaan \\
\hline 1. & $\begin{array}{l}\text { Jasa penyuluhan dan pendampingan } \\
\text { dalam mengembangkan kelembagaan } \\
\text { yang dihadiri seluruh kelompok tani } \\
\text { sumber di Desa Balecatur sebagai panitia } \\
\text { Rumah Burung Hantu hingga mandiri }\end{array}$ & $\begin{array}{l}\text { Penyuluhan dan pendampingan dilakukan dengan pendekatan secara } \\
\text { terpadu dengan cara kekeluargaan untuk konsolidasi terkait solusi } \\
\text { yang akan ditawarkan. } \\
\text { Selain kelompok tani sumber, diundang pula kelompok tani sekitar } \\
\text { dan narasumber terpercaya sebagai teladan yang telah berhasil } \\
\text { melakukan program rubuha. } \\
\text { Ditargetkan terbentuk struktur kelembagaan berupa ketua panitia, dan } \\
\text { teknisi dari kelompok tani tersebut tanpa ada unsur paksaan atau } \\
\text { kesadaran dari mitra serta sepakat dengan rencana program. } \\
\text { Sehingga output target luaran ini sebagai berikut: } \\
\text { Penentukan lokasi, jadwal, sosialisai, serta pembuatan prototype } \\
\text { rumah burung hantu untuk menunjang demonstrasi kepada warga. } \\
\text { Kerjasama yang solid diharap dapat diciptakan untuk menjadi } \\
\text { teladan. Indikator kepuasan mitra sebagai Lembaga khusus panitia } \\
\text { rubuha dilakukan dengan distribusi kuosioner dari sebelum dan } \\
\text { sesudah pelaksanaan program }\end{array}$ \\
\hline 2. & $\begin{array}{l}\text { Jasa Pendidikan terpadu dan terpantau } \\
\text { dalam memberikan metode teknis dalam } \\
\text { pembangunan, penerapan dan } \\
\text { pemeliharaan rumah burung hantu hingga } \\
\text { menyusun prosedur dalam bentuk modul } \\
\text { atau buku }\end{array}$ & $\begin{array}{l}\text { Dilakukan minimal } 4 \text { kali pertemuan formal dan monitoring terpadu } \\
\text { dari teknisi tim pengabdian hingga kelompok tani mandiri dapat } \\
\text { menerapkan program burung hantu dapat memangsa tikus yang } \\
\text { menjadi hama di lahan tersebut. Ditargetkan prosedur teknis dalam } \\
\text { pembuatan rubuha dan penerapannya ditulis oleh mitra dan dievaluasi } \\
\text { oleh tim pengabdian } \\
\text { Sehingga output target luaran ini sebagai berikut: } \\
\text { Membangun rumah burung hantu (Rubuha), menyediakan burung } \\
\text { hantu, proses karatina, dan pendampingan rutin kepada Kelompok } \\
\text { Tani "Sumber". } \\
\text { Indikator keberhasilan yaitu Burung hantu mau singgah secara } \\
\text { permanen di rumah burung hantu dan Kelompk Tani "Sumber" } \\
\text { secara mandiri dapat melaksanakan program ini. }\end{array}$ \\
\hline 3 & $\begin{array}{l}\text { Jasa penyuluhan, pendampingan dan } \\
\text { monitoring evaluasi dalam } \\
\text { merehabilitasi lahan pertanian akibat } \\
\text { rusaknya ekosistem di sekitar lahan } \\
\text { melalui pendekatan metode rantai } \\
\text { makanan sehingga diharapkan } \\
\text { menghasilkan } \\
\text { Suatu penegasan hukum kepada } \\
\text { masyarakat. Selain itu, artikel ilmiah } \\
\text { hasil pengabdian berkualitas berupa } \\
\text { jurnal nasional ISSN, prosiding seminar } \\
\text { nasional, publikasi media massa, dan } \\
\text { video }\end{array}$ & $\begin{array}{l}\text { Penyuluhan, pendampingan dan monitoring evaluasi dilakukan } \\
\text { bersamaan dengan jalannya program dan dilakukan survei terkait } \\
\text { ekosistem di sekitarnya sehingga dapat dievaluasi ke depan dalam } \\
\text { masyarakat mengeksploitasi lahan pertanian tanpa merusaknya } \\
\text { kembali. Dari program ini diharapkan outputnya dapat mendorong } \\
\text { pemerintah desa melalui kelembagaan yang kuat untuk membuat } \\
\text { peraturan desa (PERDES) yang melindungi burung hantu serta } \\
\text { habitatnya, agar tidak dirusak, diburu, atau diperjual belikan, untuk } \\
\text { kelestarian ekosistem. } \\
\text { Laporan artikel ilmiah maupun publikasi dapat dilakukan hingga } \\
\text { program selesai }\end{array}$ \\
\hline
\end{tabular}

\section{Hasil dan Pembahasan}

\section{Konsolidasi dengan mitra Kelompok Tani Sumber terkait Rencana Program}

Konsolidasi dengan mitra dilakukan dengan tujuan untuk memastikan bagaimana rencana program yang akan disesuaikan dengan kebutuhan mitra. Konsolidasi dilakukan dengan 4 pengurus kelompok Tani Sumber yang diketuai oleh Bapak Lambertus. Dilakukan survey hamparan sawah yang dimaksud selalu beriringan gagal panen selama 2 tahun terakhir ini. Kegiatan konsolidasi dengan mitra Kelompok Tani Sumber dilaksanakan pada tanggal 15 September 2020 (Gambar 2). Jadwal ini mundur dari rencana dikarenakan terdapat warga masyarakat yang terinfeksi covid 19 di dekat rumah warga terkait sebagai mitra pengabdian.

Dari hasil konsolidasi dan survei yang dilakukan, masyarakat menyambut baik akan kehadiran program pengabdian masyarakat yang akan dilakukan. Sedangkan, rencana program yang dijalankan diputuskan memiliki 4 kegiatan inti yaitu:

1. Perumusan konsep dan jenis program rumah burung hantu,

2. Penentuan lokasi habitat burung hantu dan analisis jelajahnya

3. Pemasangan rumah burung hantu, sosialisasi dengan perangkat desa dan warga masyarakat sekitar dan 


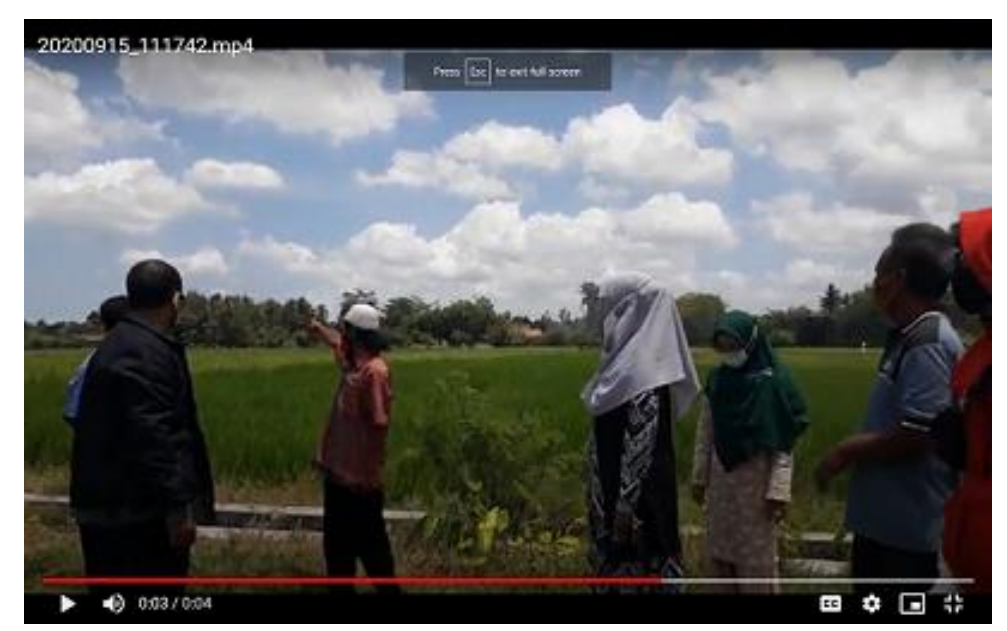

Gambar 2. Dokumentasi kegiatan survei dan konsolidasi dengan mitra kelompok tani sumber terkait rencana program

\section{Monitoring program rubuha secara intensif oleh kelompok tani}

\section{Perumusan Konsep dan Penentuan Jenis Program Rumah Burung Hantu}

Sebelum dilakukan perumusan konsep dan penentuan jenis program rumah burung hantu, tim pengabdian masyarakat dari UMY mengajak praktisi dari Balai Proteksi Tanaman, Dinas Pertanian Provinsi untuk membantu sebagai konsultan program ini (Gambar 3). Konsultan bernama Ibu Yoeke ini melakukan sharing pengalaman dengan tim dan kelompok tani terkait program yang telah dijalankan sebelumnya di berbagai daerah seperti halnya yang dilakukan di pusat studi penangkaran burung hantu Cangkringan maupun Sedayu atau program rubuha di luar kota Yogyakarta. Program rubuha memang diyakini dapat menjadi suatu cara efektif dalam pembasmian tikus di lahan pertanian dengan memperhatikan ekosistem di sekitarnya.

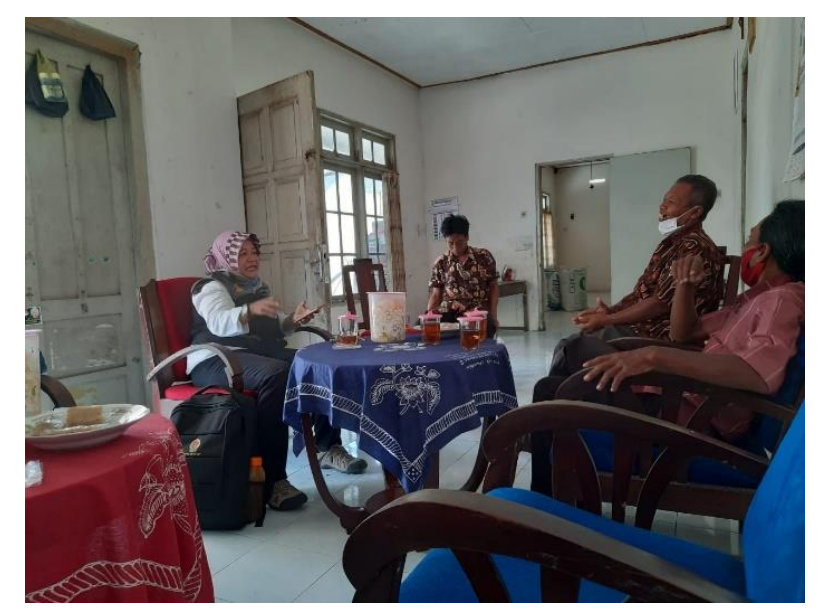

Gambar 3. Perumusan Konsep dan Penentuan Jenis Program Rumah Burung Hantu oleh tim pengabdian dari UMY, Praktisi Dinas Provinsi, dan Kelompok Tani Sumber

Konsep rumah burung hantu yang kemudian dilaksanakan berbasis pada keberadaan burung hantu yang ada di sekitar hamparan sawah di mana menjadi lahan yang diminati populasi tikus yang menjadi hama penyebab kegagalan panen petani hingga saat ini. Oleh karena itu kemudian dilakukan suatu analisis daya jelajah burung hantu. 


\section{Penentuan Lokasi Habitat Burung Hantu dan Analisis Jelajahnya}

Kegiatan selanjutnya dilakukan oleh sejumlah anggota dari kelompok tani sumber untuk mengetahui keberadaan lokasi habitat burung hantu dan analisis jelajahnya (Gambar 4) yang dilaksanakan selama 7 hari berturut turut yang dilakukan oleh kelompok tani sumber secara bergilir dimulai dari 21 Oktober 2020. Tujuan dilakukan kegiatan ini yaitu untuk menentukan titik lokasi penanaman rumah burung hantu sebagai sarana penangkaran burung hantu. Lokasi habitat dari burung hantu yang telah ada di Kawasan hamparan sawah memiliki 2 area yaitu suatu sekolah dasar dan rumah milik ketua rumah tangga.
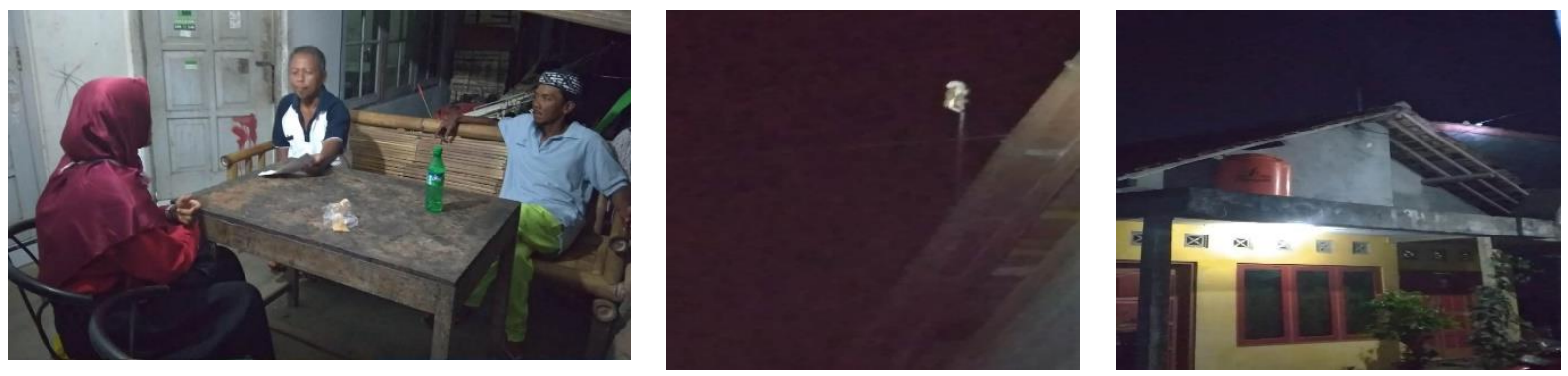

Gambar 4. Dokumentasi kegiatan analisis jelajah yang dilaksanakan selama 7 hari berturut turut yang dilakukan oleh kelompok tani sumber secara bergilir

Berdasar teori bahwa rumah burung hantu perlu ditanam pada 50 meter lokasi dari keberadaan lokasi habitat asal burung hantu tersebut. Kemudian peletakan arah didasarkan pada arah jelajah dari burung hantu tersebut. Sehingga, dapat dipastikan dapat melewati rumah burung hantu dan tenggeran yang dipasang. Terdapat 2 rumah burung hantu yang akan dipasang pada area ideal tersebut (Gambar 5) sebagai titik lokasi dari peletakan rumah burung hantu berdasarkan analisis jelajah burung hantu.

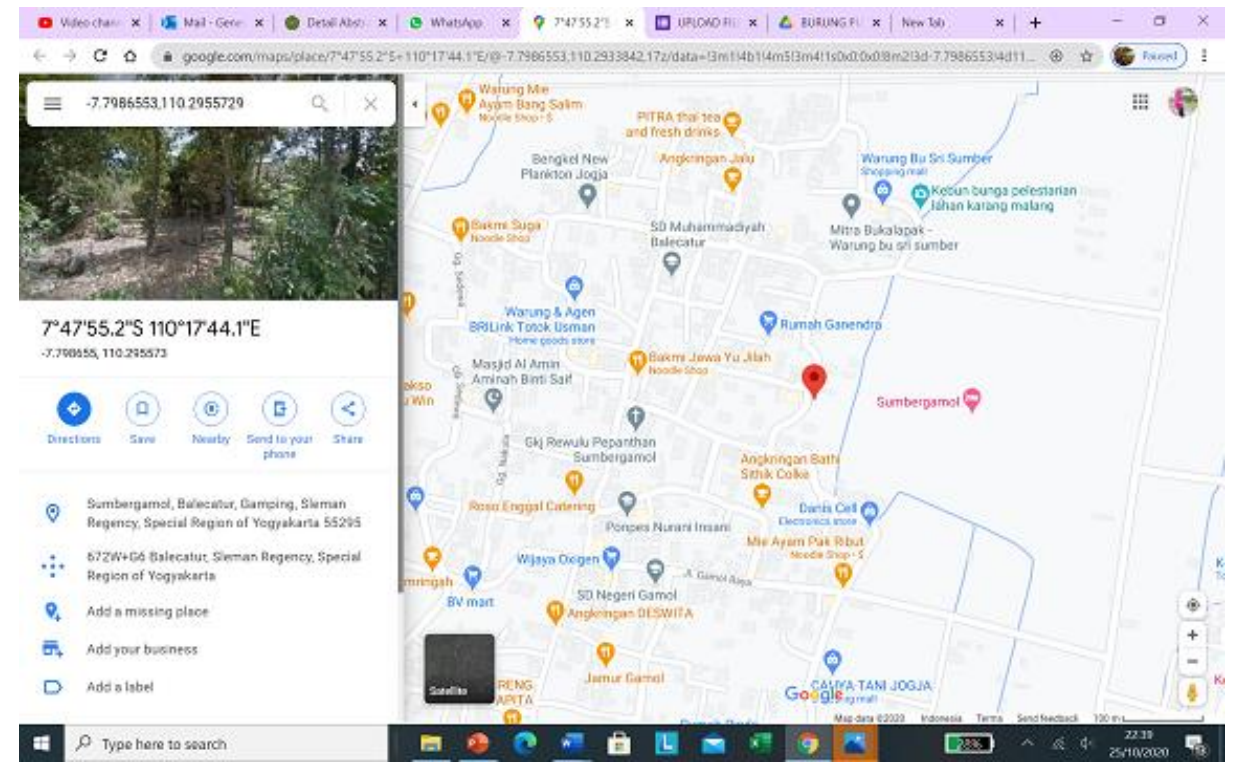

Gambar 5. Titik lokasi dari peletakan rumah burung hantu berdasarkan analisis jelajah burung hantu.

\section{Pemasangan Rumah Burung Hantu, dan Sosialisasi Dengan Perangkat Desa Dan Warga Masyarakat Sekitar}

Rumah burung hantu berjenis Tyto alba yang didesain disesuaikan dengan standar dari rumah pada umumnya untuk burung karnivora pemakan tikus. Berikut Gambar 6 merupakan 
rumah burung hantu yang dimaksud dengan ketinggian 6 meter dengan tinggi menancap di permukaan setinggi 5 meter.

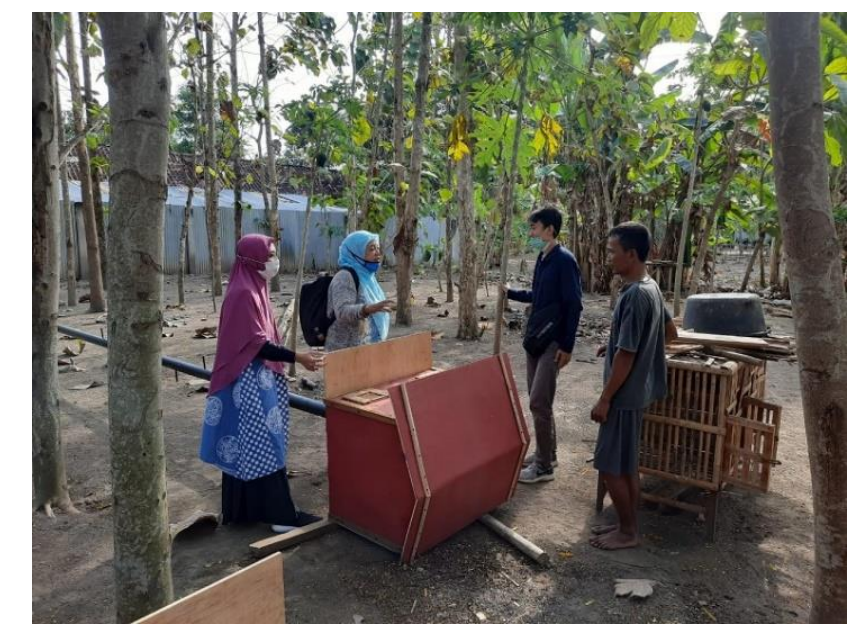

Gambar 6. Desain rumah burung hantu sebagai sarana penangkaran burung hantu di Kawasan hamparan sawah milik kelompok tani Sumber

Sosialisasi mengenai pemasangan rumah burung hantu dilaksanakan pada tanggal 30 Oktober 2020 dengan mengundang perangkat desa sehingga dapat dilakukan perumusan hukum melalui peraturan desa dalam melestarikan burung hantu sebagai sahabat petani dalam membasmi tikus. Setelah sosialisasi, pemantauan burung hantu dilakukan secara intensif dari pengurus inti kelompok tani sumber dan warga sekitar sehingga program ini dapat lambat laun menjadi kunci pemberantasan populasi tikus di hamparan sawah

\section{Simpulan}

Program kemitraan masyarakat dengan tujuan pengendalian tikus di lahan pertanian melalui program rumah burung hantu didasarkan pada keberadaan burung hantu tyto alba di kawasan dekat hamparan sawah milik kelompok tani sumber. Pelaksanaan rubuha ini perlu didukung oleh seluruh anggota masyarakat baik kelompok tani bersangkutan, warga sekitar, maupun perangkat desa yang bertugas dalam pengaturan hukum dalam proses pelaksanaannya.

\section{Ucapan Terima Kasih}

Ucapan terimakasih disampaikan kepada LP3M UMY yang telah memberikan dana program kemitraan kepada masyarakat didanai tahun 2020 dengan nomor kontrak 031/PEN$\mathrm{LP} 3 \mathrm{M} / \mathrm{I} / 2020$.

\section{Daftar Pustaka}

K, R. A., Mangoendiharjo, S., Wagiman, F., \& Djuwantoko 2006. Habitat Burung Serak (Tyto alba javanica) Pemangsa Tikus pada Ekosistem Persawahan Di Kabupaten Kendal'. Prosiding Seminar Nasional Hasil Penelitian Pertanian, pp. 212-222.

Setiabudi, J., Izzati, M. \& Kismartini, 2015. Analisis Prioritas Kebijakan Pemanfaatan Burung Hantu (Tyto alba) sebagai Pengendalian Hama Tikus Sawah yang Ramah Lingkungan di Kabupaten Semarang'. Indonesian Journal of Conservation, pp. 67-73. 